\title{
Analysis of the Relation between Macroprudential and Microprudential Policy
}

\author{
Nada Blahova
}

\begin{abstract}
:
The article deals with the analysis of a relationship between macroprudential and microprudential policy on a general level and on an example of regulatorily required structure and volume of bank capital. Regulatory requirements and supervisory methods are described in connection with the institutional structure of regulation and supervision within the European economic area. An attention is paid to the development of supervision on an individual basis through consolidated supervision to supplementary supervision of financial conglomerates, which corresponds with the activity and structure of the financial sector, high rate of integration and transboundary action of financial groups headed by a bank. The European System of Financial Supervision and Single Supervisory Mechanism are presented. Development of the regulation of bank capital is analysed. The original microprudential approach is mentioned that involved macroeconomic impacts from its introduction. Based on the analysis of capital structure as conceived from Basel I to Basel III approaches of regulation to this important indicator are discussed. Instability sources and indicative instruments of macroprudential policy are analysed on an example of the excessive growth of credits and leverage as an instability source and countercyclical capital buffer, sectoral capital requirements and leverage ratio in the role of indicative instruments.
\end{abstract}

Key words: Bank; Capital; Macroprudential policy.

JEL classification: G21, K23

\section{Introduction}

Prudential policy rules as a set of regulatory requirements have been applied to credit institutions and investment companies in the long run. Greater demands, increasingly larger scope of requirements, efforts aimed at international consistency of the approach and newly also distinction of macro-level and microlevel are typical for the development of prudential policy rules. The concepts macroprudential and/or microprudential supervision, rules, policy are reflected in the institutional structure of regulation and supervision of the financial sector. This article is focused only on the banking sector. The actual prudential policy approach responds to a declaration of the G20 from 2009 about strengthening the financial system and includes a number of measures leading to strengthening the

Ing. Nada Blahova, Ph.D., - Senior Lecturer; Faculty of Finance and Accounting, University of Economics, Prague, W. Churchill Sq. 4, 13067 Prague, Czech Republic, <blahova@vse.cz>.

The article is worked out as an output of a research project of the Department of Finance and Accounting of VŠE. The project is realized within the Institutional support of VŠE IP100040 and project IG106014. 
banking sector regulation. The final version of the prudential policy measure is called Basel III and it was elaborated in the Basel Committee on Banking Supervision (BCBS 2011). For banks in the European Economic Area (EEA) the Capital Requirements Directive (CRD IV) along with the Capital Requirements Regulation (CRR) are decisive documents.

Besides documents issued by official institutions there are some scientific publications supporting the need of changes. The ways of stabilizing the financial sector as a reaction to financial crisis were sought (among others) by Calomiris (2012), who wrote about unprotected sources of funding and about the need of improving the regulatory capital of banks. Ayadi (2008) discussed the relationship between economic and regulatory capital and inclined to recommend improving the quality of bank capital. E.g. Herring (2011) accentuated a downward trend of the capital magnitude. Cannata and Quagliariello (2009) revealed another negative phenomenon - excessive risk-taking by banks. The necessity to coordinate the efforts of eliminating future crises and their transboundary impact was emphasized by Lall (2009).

The creation of new supervisory architecture of the EEA financial system was initiated by the de Larosière report (2009), that identified the causes of financial crisis and proposed to create the uniform set of rules on a European level that would strengthen the EEA financial system. The objective of the new arrangement is not only to focus on the supervision of financial institutions but also to be responsible for the financial stability of the whole European financial area.

In documents dealing with the present approach to the financial market supervision and with the rules of the activity of financial institutions it is not always specified explicitly whether it is regulation or supervision. These concepts are combined, confounded or used as alternatives. For greater transparency of this article the concept regulation is used in the context of defining the rules for bank activity and the concept supervision is used as the control of observation of regulatory rules (Revenda 2011).

The objective of the present article is to analyse the relationship between macroprudential policy and microprudential policy and their impact on the new architecture of institutional structure of regulation and supervision in the EEA. The analysis on a general level results in the analysis of development of requirements for one of the crucial areas of regulation - bank capital. The newly designed conception of capital structure contains both the microprudential and macroprudential component that is discussed in relation to objectives and instruments of macroprudential policy. 


\section{Institutional structure}

So that the regulation and supervision of the financial market will be functional and efficient, the institutional structure of regulation and supervision should adequately reflect the activity and structure of the financial sector, mutual relations of financial institutions, their high level of integration and frequent transboundary action. The majority of the financial institutions do not act in the market separately but are parts of financial groups being present in more than one EU country or in the third countries. It is necessary to respond to such a situation.

\subsection{History of an approach to supervision on a general level}

At first the approaches to supervision were only set on an individual basis. The goal was to verify the observation of prudential policy requirements by a bank. Currently, the importance of such an approach is not diminished but it is not the only type of supervision any longer. There also exists a supervision of regulated entities on a consolidated basis. The goal of the application is to assess the risks for the bank arising not only from its own activities but also from its incorporation into a consolidation complex. It is necessary to identify relations between the entities that are a part of the consolidation complex and the bank, and to focus on risks within the whole financial group that could threaten the bank as a member of the group. This approach is adopted by the consolidation complex whose part the bank is. It is not a substitution of supervision on an individual basis neither is it a supervision of all entities of the complex.

Although in reaction to the application of supervision on a consolidated basis a possibility of regulatory arbitrage was substantially limited, it was necessary to respond to the existence and activity of large supranational financial groups with the highly interconnected particular sectors of financial services, which was reflected in the introduction of supplementary supervision of financial conglomerates.

\subsection{Present institutional structure on a supranational level}

The actual form of the institutional structure includes entities that were gradually established for this purpose and that started creating the supervisory architecture within the EU, mainly in reaction to the financial crisis. The European Central Bank (ECB) joined as the last in November 2014. Surely, it is not to state that competences and responsibilities would be clearly defined within the group that involves both approaches - microprudential and macroprudential ones. For the final functional form necessary reporting from the level of domestic supervisory structures should be available. This requirement is difficult to meet because it is important to note that no uniform domestic arrangement of regulation and supervision exists in the EU member countries. 


\subsection{European System of Financial Supervision}

The system was formulated on the basis of recommendations of the 2009 de Larosière report (2009), which can be considered as a background document. The objective of the European System of Financial supervision (ESFS) is to provide a complex oversight of the EEA financial system. Several institutions are components of the ESFS - the activity of some of them is relevant for the investigation of bank regulation and supervision. These are European Banking Authority (EBA), whose activity is aimed at the area of microprudential policy and European Systemic Risk Board (ESRB), whose activities correspond with macroprudential policy and hence with the concern for financial stability.

\subsection{Single supervisory mechanism}

In November 2014 the European Central Bank (ECB 2014) assumed a significant role in the framework of the EU supervisory architecture and introduced the Single Supervisory Mechanism (SSM 2013), which the respective national competent authorities (NCA) of the Euro area states will participate along with the ECB in. The objective of this grouping is to apply consistent supervisory methods, to strengthen the supervisory prudence toward credit institutions and to increase the financial market stability.

One of the main goals is not only to focus on the regulation and supervision of particular financial institutions but also to be concerned with the financial system stability as a whole. The principles the single supervisory mechanism wants to respect are based on the arrangements of BCBS. Main principles, their analysis and interpretation are shown in the table below.

\section{Tab. 1: Principles of supervision and their interpretation}

\begin{tabular}{ll}
$\begin{array}{l}\text { Principles of } \\
\text { supervision }\end{array}$ & Interpretation \\
\hline $\begin{array}{l}\text { Time-proven } \\
\text { practices }\end{array}$ & $\begin{array}{l}\text { Use of modern supervisory practices while respecting the experience of } \\
\text { national supervisory authorities and internationally recognized criteria. } \\
\text { Continuous revision of methodologies, updating. } \\
\text { Consistency of results as an outcome of cooperation of all participants. Use of } \\
\text { decentralized practices (collection of quantitative and qualitative information) } \\
\text { integrity and } \\
\text { decentralization }\end{array}$ \\
$\begin{array}{l}\text { Homogeneity } \\
\text { within SSM }\end{array}$ & $\begin{array}{l}\text { Principles and practices of supervision should be applied toward all } \\
\text { institutions of every participant country in an adequately harmonized way. }\end{array}$ \\
\hline $\begin{array}{l}\text { Prevention of differences and fragmentation. } \\
\text { Harmony with } \\
\text { single market }\end{array}$ & $\begin{array}{l}\text { The goal is a better solution to systemic risks, uniform set of rules with the } \\
\text { awareness of a high number of jurisdictions. Openness toward the member } \\
\text { states outside the Euro area. }\end{array}$ \\
$\begin{array}{l}\text { Independence and } \\
\text { accountability }\end{array}$ & $\begin{array}{l}\text { democratic accountability. The goal is confidence in the single supervisory } \\
\text { mechanism. }\end{array}$
\end{tabular}


European Financial and Accounting Journal, 2015, vol. 10, no. 1., pp. 33-47.

\begin{tabular}{ll}
\hline $\begin{array}{l}\text { Principles of } \\
\text { supervision }\end{array}$ & Interpretation \\
\hline $\begin{array}{l}\text { Risk-based } \\
\text { approach }\end{array}$ & $\begin{array}{l}\text { It is based on a probability of emerging risk occurrence and its impact on the } \\
\text { profit and loss statement of supervised institutions. The influence of potential } \\
\text { defaults on financial stability is assessed. }\end{array}$ \\
\hline Proportionality & $\begin{array}{l}\text { The systemic importance of supervised institutions and their risk profile will } \\
\text { always be respected. The intensity of supervision will differ with respect to } \\
\text { limiting resources designed for the execution of supervision. }\end{array}$ \\
Adequate level of & $\begin{array}{l}\text { Regardless of the perceived risk of default the minimum and simultaneously } \\
\text { sufficient level of supervision will be applied to all institutions. Institutions } \\
\text { will be categorized by the influence of their potential default on financial } \\
\text { stability and the minimum level of engagement will be defined for each level. }\end{array}$ \\
A close relationship between the assessment and corrective action will be \\
pushed through. It has to be timely and effective. The goal is protection of \\
public resources, and minimization of dependence on public support.
\end{tabular}

Source: ECB (2014a) pp. 6-9, authorial computation.

\section{Prudential requirements on a micro and macro level}

Microprudential and macroprudential approaches mutually influence each other. Basel III contains and combines both these levels when the focus is traditionally on a microprudential level while macroprudential requirements are further developed and specified in the documents of ESRB. These two levels are not absolutely isolated. Besides new, explicitly macroprudential instruments there exists a range of microprudential instruments that can be potentially modified and applied in the framework of macroprudential policy. The financial system can be perceived as a whole, which is not the same as an aggregate of particular financial institutions. It is true that demanding requirements on the micro-level, aimed at the support of prudential business of banks, imply higher resistance of banks and reduce the systemic risk. The object of the analysis is requirements for the capital structure and volume of banks.

\subsection{Analysis of regulatory capital}

If the development of requirements for the capital equipment, structure of regulatory capital, is analysed, we can see the initial completely microprudential approach which actually responds to the needs of influencing the systemic risk and also involves macroprudential requirements. The first regulatory rule of capital adequacy comprised arrangements exerting an indirect influence on a macroeconomic level but this influence was mostly negative. The presently defined requirements for capital structure and volume react, inter alia, to the previous, less suitable conceptions.

The regulation of capital adequacy was first formulated in 1988 in the document International Convergence of Capital Measurement and Capital Standards, currently referred to as Basel I (BCBS 1988). It concerned only the credit risk of banks while the ratio of regulatory capital to risk-weighted assets (RWA) was 
determined at a level of minimally $8 \%$. The capital structure for the calculation of capital adequacy had to respect a requirement for the minimally $50 \%$ presence of so called core capital (Tier 1, core capital). It included paid-up capital and disclosed reserves. The maximum includible level of supplementary capital (Tier 2 ), which was less reliable compared to Tier 1 , was restricted by the magnitude of Tier 1. In the last five years to maturity the includible part of subordinated debt was decreased by $20 \%$ a year. The maximum recognizable level was $50 \%$ of Tier 1. The recognition of supplementary capital components was up to decisions of national competent authorities of banking supervision.

In 1996 the Capital Accord of BCBS (1996) was adopted where market risks, besides credit risk, were included in the calculation of capital adequacy. Tier 3 was added to the definition of capital setting down that this component of total capital might cover only the capital requirement for market risks. It included a short-term subordinated debt, which the original maturity of two years was required for; it could not be secured and paid up before contractual maturity. Tier 3 capital was subjected to two restrictions. It could not exceed the 2.5 multiple of the capital (Tier 1 and Tier 2) that will remain disposable after the credit risk has been covered, and at the same time the sum of Tier 2 and Tier 3 was not allowed to exceed the Tier 1 core capital.

A negative aspect of such an approach that had macroeconomic impacts was that the quality of particular credit exposures was not respected when the $100 \%$ risk weight was applied to all private non-bank clients regardless of the assessment of probability of their default. It was an impulse of preferring the allocation of bank resources to the government debt (e.g. to treasury bills) instead of financing the private sector. In relation to receivables from countries or secured countries a division into OECD members and non-members, regardless of the actual economic situation of the country, is evaluated negatively.

\subsection{Effort of approaching to economic capital}

Developments in financial markets claimed radical changes in the regulatory approach. It was necessary that the required regulatory capital would better correspond to economic capital that was determined by banks for risk management on the basis of often highly sophisticated models of risk measurement and management. Based on Basel II, the first consultative material of which was issued in 1999, the best practice approaches, and hence the more precise determination of regulatory capital, were to be adopted. It was expected that it would be brought closer to economic capital and/or it would be decreased by virtue of better measurement of credit risk that was designed in the framework of Basel I in a too simplified way. The banks were about to use such a difference to cover the operational risk while the unchanged level of the newly conceived total capital requirement compared to the previous conception was assumed. After introduction 
of the new arrangement the capital of each bank was assumed to respond in a better way to its risk profile and/or risks that are incurred.

The creation of a new regulatory approach was more difficult than expected and the original time schedule failed to be implemented. The first version underwent a thorough revision. The original goal of lower capital requirement for banks with the acceptable risk profile was not successfully realized. On the contrary, the opponents' opinions warned about the higher need of capital not only for the application of a standardized method but also for the application of more advanced methods (internal ratings-based approach IRB). The whole process was concluded in 2004 (BCBS 2006).

\subsection{Procyclicality of Basel II - macroprudential aspect}

From the macroprudential aspect Basel II contains problems related to evident procyclicality that results from the processes of banking business and is still enhanced by the involvement of external rating into the calculation of capital requirement for credit risk of the investment portfolio mainly in so called standardized approach (Altman, Saunders 2001). It is true that economic expansion is usually accompanied by credit expansion. Banks are making significant gains that may become a source of increasing their capital. A subsequent period of recession makes the majority of banks draw on their reserves and cover potential losses. The ratings of rating agencies, which are largely represented in relation to the calculation of capital requirement for credit risk, are of procyclical nature. They reach the worst values at the end of recession, not at its beginning, which would facilitate its indication. Ratings react to actual development, and they are not able to predict it. There is a correlation between economic expansion and subsequent crisis of the banking system. The boom brings the greatest credit risk while the recession is characterized by a low credit risk. Capital buffers should be created in the phase of expansion and they should be drawn on in the period of recession. But the creation of ratings reacting to expected development would also be assumed. However, the assessment of rating agencies is derived rather from the phase of the cycle in which the economy is just now and so it acts in the direction of accentuating the phases of the cycle procyclically (Monfort, Mulder 2000). The improvement is up to the regulator who may define different requirements for the capital for different phases of the business cycle, which is advocated by Basel III.

The new regulatory framework - Basel III - revises and improves the arrangements of Basel II and its actual version for the area of capital dates back to 2011 (BCBS 2011). Compared to Basel II, regulatory capital according to Basel III is obligatorily explicitly specified with emphasis on higher quality, consistency and transparency. It consists of the sum of the components Tier 1 going concern capital and Tier 2 gone concern capital while Tier 1 is divided into the primary and secondary part. The capital should be stable in time and for this reason a part of 
common equity Tier 1 capital is accentuated and proportionally strengthened, in which capital instruments such as paid up capital stock, capital surplus, reserve requirements, retained profit from the preceding period and profit from the current period can be included. It is important to respect a number of demanding criteria conditioning a possibility of including financial instruments in the respective parts of regulatory capital. Besides the highest-quality component, it is possible to include in total Tier 1 , in the framework of secondary Tier 1, debt instruments having the character of both the capital and the liability, perpetual issues of preferred stock and other instruments on whose maturity the issuer can decide with the regulator's approval after the lapse of five years. The liabilities must comprise a call option for transformation to shares of the bank. Tier 2 capital must meet specific verifiable criteria. Among others, subordinated debt with five-year maturity at least, surplus of created adjusting items above the identified expected loss in relation to the IRB approach. If adjusting items exceed the expected loss, supplementary capital can also be created for banks applying the standardized approach, with the upper limit of 1: $25 \%$ of risk-weighted assets.

Total capital (Tier 1 plus Tier 2) was left at the level of $8 \%$ RWA. The objective as a strengthening of the highest-quality component of capital is set in time as follows: since 2013 the Tier 1 ratio has increased from $4.5 \%$ to $6 \%$. The requirement for the Tier 1 core capital is about to increase from $3.5 \%$ to $4.5 \%$ in 2015. Banks are obliged to hold minimally $4.5 \%$ of RWA as common stock capital. Basel II required $2 \%$. Regulatory capital should account for $10.5 \%$ of RWA in total and the capital conservation buffer at a level of $2.5 \%$ may increase the resultant value. The table below shows the time schedule of changes in capital.

\section{Tab. 2: Time schedule of changes in capital (in \%)}

\begin{tabular}{lccccccc}
\hline & $\mathbf{2 0 1 3}$ & $\mathbf{2 0 1 4}$ & $\mathbf{2 0 1 5}$ & $\mathbf{2 0 1 6}$ & $\mathbf{2 0 1 7}$ & $\mathbf{2 0 1 8}$ & $\mathbf{2 0 1 9}$ \\
\hline $\begin{array}{l}\text { Minimum common equity capital ratio } \\
\text { Capital conservation buffer }\end{array}$ & 3.5 & 4.0 & 4.5 & 4.5 & 4.5 & 4.5 & 4.5 \\
$\begin{array}{l}\text { Minimum common equity plus capital } \\
\text { conservation buffer }\end{array}$ & 3.5 & 4.0 & 4.5 & 5.125 & 5.75 & 6.375 & 7.0 \\
Phase-in of deductions from CET1 & & 20 & 40 & 60 & 80 & 100 & 100 \\
Minimum Tier 1 capital & 4.5 & 5.5 & 6.0 & 6.0 & 6.0 & 6.0 & 6.0 \\
Minimum total capital & 8.0 & 8.0 & 8.0 & 8.0 & 8.0 & 8.0 & 8.0 \\
$\begin{array}{l}\text { Minimum total capital plus conservation } \\
\text { buffer }\end{array}$ & 8.0 & 8.0 & 8.0 & 8.625 & 9.25 & 9.875 & 10.5 \\
\hline
\end{tabular}

Source: BCBS 2011, authorial computation.

Basel III reacts to the need of procyclicality reduction. The objective is to an establish equilibrium between risk sensitivity and stability of capital requirements. Considering the high ratio of capital requirements for credit risk, the solution should be based on a demand on the use of long-term data horizon for estimating probability of default (PD), introduction of estimation of loss given default (LGD) 
under recession and appropriate calculation of risk functions that can project loss estimations into regulatory capital requirements. Stress testing is also advisable when the transfer of credit portfolios to lower rating classes is assumed in the period of recession. As stated in connection with problems of Basel II application, after the period of an excessive increase in credit issue a recession follows when the debt service for key debtors of banks becomes difficult, the quality of receivables of banks is impaired, the need of the creation of adjusting items increases and all these factors have a negative impact on the profit and loss statement of banks. It is to note that capital is more expensive than the other forms of financing, so a countercyclical reserve should be created. The main goal is sufficient capital of the banking sector so that it will able to provide credits without putting its solvency in jeopardy.

Capital conservation buffer is set above the minimum regulatory capital requirements of Tier 1 and accounts for $2.5 \%$ of RWA. It has to be capable of fully absorbing losses. If there is a decrease in capital adequacy and the bank must use this contingency reserve for covering losses, it has to retain a higher percentage of its incomes and restrict the distribution policy, e.g. dividend payout (Caruana, 2010).

A reserve to cover the systemic risk is required only from banks that were designated, on the basis of evaluating a number of indicators, as systemically important. In these banks a strong risk of interbank contagion is imminent and their destabilization would threaten the financial system stability. These banks should have a higher loss-absorbing capacity. This is consistent with an additional requirement for capital and/or for the ratio of minimum capital requirement to RWA in the range of 0.5 to 2.5 percentage points. A potential reduction in financial aid by the government may also bring about an effect.

From an empirical observation that low risk weights may lead to excessive systemic risks there has arisen a requirement for the leverage ratio that may identify the risks which were not covered by capital requirements through risk weights. The ratio will restrict the absolute magnitude of bank debt for a given amount of capital. We are now in the testing period (until 2018), which the relation between Tier 1 capital and total bank exposure at a level of $3 \%$ is applicable for.

Capital buffers represent a certain extension of regulatory capital and are designed to be instruments of macroprudential policy while in the case of contingency reserve they are a component of microprudential capital requirement at the same time. 
Blahova, N.: Analysis of the relation between macroprudential and microprudential policy.

\section{Tab. 3: Macroprudential capital buffers}

\begin{tabular}{ll}
\hline Type of reserve & Description and purpose of the reserve \\
\hline Countercyclical buffer & $\begin{array}{l}\text { Designed for mitigation of fluctuations in credit dynamics that deepen the } \\
\text { business cycle } \\
\text { Created in the period of an excessive increase in credit issue and used to } \\
\text { cover losses during recession } \\
\text { Designed for all banks for capital maintenance } \\
\text { Tier 1 equity capital }\end{array}$ \\
& $\begin{array}{l}2.5 \% \text { of the total volume of risk exposure, the rate does not change in time } \\
\text { Designed for systemically important banks }\end{array}$ \\
systemic risk & The rate is determined on the basis of evaluating the set of indicators
\end{tabular}

Source: BCBS 2011, ESRB 2013, authorial computation.

\subsection{Macroprudential policy}

Macroprudential policy, which is currently understood as an important part of economic policy, has been accentuated in response to the world financial crisis. The concept, which was used only by BCBS in the past, became frequent mainly in connection with an effort to prevent the origin of systemic risk and to ensure financial stability. An extraordinary importance attributed now to macroprudential policy has been reflected also in the institutional area. Besides BCBS, Financial Stability Board (FSB) is the most important forum, whose goal is, on the G20 initiative, to coordinate on a global level the authorities responsible for financial stability. It cooperates with the International Monetary Fund (IMF), and with national and regional regulatory and supervisory structures. In the framework of ESFS the European Systemic Risk Board (ESRB) is responsible for macroprudential supervision of the financial system in the European Union. The mandate for macroprudential policy on a national level was formulated by this board for the member countries; the Czech National Bank is a responsible institution in the Czech Republic.

\subsection{Selected sources of instability and respective instruments}

In this article selection is focused on macroprudential consequences of requirements for the capital equipment of banks, reduction in insolvency risk and systemic risk. The risk of interbank contagion, so called domino effect, is a related issue, reflected in an increase in systemic risk. This area also comprises a requirement for the calculation of leverage ratio. The macroprudential dimension can be found mainly in determining the obligation of banks to maintain the respective capital buffers. The table below documents only those selected sources of instability that are interpreted in this article in relation to capital, and selected indicative instruments whose application should ensure the alleviation or exclusion of instability sources, which is the goal of macroprudential policy. 
Tab. 4: Source of instability and respective instruments

\begin{tabular}{|c|c|}
\hline $\begin{array}{l}\text { SOURCE OF } \\
\text { INSTABILITY }\end{array}$ & INDICATIVE INSTRUMEN \\
\hline \multirow{3}{*}{$\begin{array}{l}\text { Excessive increase in credits } \\
\text { and leverage }\end{array}$} & Countercyclical capital buffer \\
\hline & Sectoral capital requirements \\
\hline & Leverage ratio \\
\hline
\end{tabular}

Source: ESRB 2013, authorial computation.

The effects of these instruments are not isolated but many times they complement each other while in general some influence cyclical aspects and others structural aspects of systemic risk. Cyclical aspects of systemic risk correspond with the behaviour of banks, which in the period of strong economic growth accept excessive risk while accentuating risk aversion in the opposite phase of the business cycle. Such behaviour leads to a deepening of the phases of the cycle and may cause a number of problems in real economy. On the contrary, structural aspects of systemic risk correspond with the risk profile of the given financial system.

\subsection{Analysis of instruments limiting excessive growth of credits and financial leverage}

a) Countercyclical capital buffer

It is systemic risk buffer (SRB) and countercyclical capital buffer (CCB). In dependence on the phases of the credit cycle it is suitable to either increase or to decrease the countercyclical capital buffer. If there is an excessive credit issue growth, it enhances the growth of systemic risk, which should correspond with an increase in capital buffer. This type of reserve may indirectly cause a decrease in the supply of credits or an increase in the costs of debt service, limiting the expansive period of the credit cycle in this way. The issue of credits is reflected in the volume of risk-weighted assets whose potential reduction may positively influence the indicator of capital adequacy.

b) Sectoral capital requirements

The use of countercyclical capital buffer is limited to some extent by its general application. This deficiency can be compensated by the use of so called sectoral capital requirements when a different, higher rate of capital requirement is used toward a definite sector or group of sectors or group of assets to cover systemic risk. This sophistically set capital requirement will bring about, with a high level of probability, a reduction in the issue of credits for a definite sector or group of sectors or group of assets due to an increase in financing costs. It potentially looks very efficient. 
Blahova, N.: Analysis of the relation between macroprudential and microprudential policy.

c) Leverage ratio

When risks are not taken into account and if they are not projected to classes of risk-weighted assets, we are working with total assets only, and the equity capital to total assets ratio results in so called leverage ratio. The causative chain of relations when the leverage ratio is used can be estimated in the following way. In case that the ratio is set more strictly than the requirements for risk-weighted assets, the banks will either decrease the sum of assets or increase their equity capital to respect the regulatory requirement. It will be reflected in a decrease in credit issue.

In the choice of macroprudential policy objectives and instruments it is to respect that only the stable financial system can support to a sustainable extent desirable economic growth. For each continuous objective of macroprudential policy one or several selected instruments should be used. It is always advisable to choose such an intensity of selected instrument that it will efficiently contribute to the financial cycle stabilization. A necessary condition for the application of such instruments is legislation. If they are not laid down by the respective legal regulations of EEA, they can be applied on a domestic level in accordance with appropriate legislation.

The instruments presented in the article have not always been subjected to a complex quantitative analysis that would support the approval of their efficiency and effectiveness. The experiences with their application have been limited until now even though the article is intentionally focused on those of the potential instruments that have received relatively sound estimations of their expected effects. Moreover, the fulfilment of standards that are a basis for the application of macroprudential policy is to start gradually. Currently, they are mostly monitored only and their final form is not known completely yet. In addition, we are in the period of monitoring when potential corrections are assumed that will increase the resistance of banks to shocks without negatively limiting the economic growth, mainly long-term investments.

Nowadays, some difficulties of application are to be predicted. E.g. determination of an optimum level of regulatorily required countercyclical capital buffer is not either easy or unambiguous matter. The monitoring of a long-term trend of the ratio between credits and GDP seems promising. Selective action is more suitable, but only on condition that the sectors or groups of assets toward which the reserve will be applied are correctly identified. The situation can be clearly demonstrated on the approach of CNB to macroprudential policy CNB 2014). The present rate of countercyclical capital buffer is set at $0 \%$. The central bank is reasoning this value by the analysis of indicators such as activity in credit market, the ratio of the private sector running into debts to the development of its revenues, prices of residential immovable property, etc. It is also argued that the CR is nowadays in the phase of initial moderate recovery. Obviously, there is an advantage of defining macroprudential policy when recommendations are formulated on the 
supranational level and thanks to the mandate national institutions accountable for financial stability can take decisions on the basis of a specific domestic situation.

\section{Conclusion}

The original regulatory approach was a microprudential one using the present terminology. But the rules have had secondary macroeconomic effects since their adoption. The main problem was the support of the procyclical behaviour of banks set already in Basel I, and due to a great involvement of external ratings it was strengthened in Basel II. The change in the present conception is an effort to influence in advance the financial system as a whole with respect to its stability and need of economic growth, to mitigate the procyclical behaviour of the banking sector, to act in a macroprudential way. The official definition of macroprudential policy with the aim to intentionally influence in advance the stability of financial market by means of regulatory rules of macroprudential character was beneficial. But the regulation still consists in the formulation of rules for the activity of particular banks. Based on the analysis of capital structure and development of requirements for capital, obviously the micro- and macro-level cannot be absolutely separated. It is to evaluate positively the strengthening of the highestquality component of capital, generating of a number of demanding and specific qualification criteria for financial instruments that are to be incorporated into the capital components and an opportunity of the national supervisory authorities to choose the optimum level of capital buffers with regard to the specific situation of a given country.

A parallel to the development of regulation can be seen in the development of an approach to banking supervision when besides the originally applied supervision on an individual basis, consolidated supervision and later on supplementary supervision of financial conglomerates were introduced. Such development of supervisory approaches confirms the need of limiting regulatory arbitrage and respecting the existence of financial groups that are often active on a supranational level. Nevertheless, it is not a substitution of supervision on an individual basis, which has remained the basis of supervisory activity, similarly like a microprudential approach is a crucial method in the area of regulation. Currently, major attention is paid to supervision within Europe represented by the European System of Financial Supervision and by the Single Supervisory Mechanism. Although the latter is designed for the Euro area, as a result, it is not quite a harmonized supervisory architecture. The European approach to both the regulation and the supervision is characterized by a large range of implementing regulations that are objectively less transparent compared to Basel III. 


\section{References}

Altman, E. I., Saundets, A., 2001. An Analysis and Critique of the BIS Proposal on Capital Adequacy and Ratings. Journal of Banking and Finance 25, 197-270.

Ayadi, R., 2008. Basel II Implementation in the Midst of Turbulence. Centre for European Policy Studies. Task Force Report.

BCBS, 1988. Bank for International Settlements, Basel Committee on Banking Supervision, International Convergence of Capital Measurement and Capital Standards, Basel.

BCBS, 1996. Bank for International Settlements, Basel Committee on Banking Supervision, Amendment to the capital accodr to incorporate market risks, Basel.

BCBS, 2006. Bank for International Settlements, Basel Committee on Banking Supervision International Corvergence of Capital Measurement and capital Standards, Basel.

BSBC, 2011. Bank for International Settlements, Basel Committee on Banking Supervision, Basel III: A global regulatory framework for more resilient banks and banking systems. Revised version June 2011, Basel.

Calomiris, CH. W., 2012. How to Regulate Bank Capital. National Afffairs 10, 41-57.

Cannata, F., Quagliariello, M., 2009. The role of Basel II in the subprime financial crisis: guilty or not guilty? Centre for Applied Research in Finance, Working Paper n. 3/09, Milan.

Caruana, J., 2010. Basel III: towards a safer financial system. Speech at the 3rd Santander International Banking Conference, Madrid.

ČNB, 2014. Česká národní banka. Proticyklická kapitálová rezerva. Available from: <http://www.cnb.cz/cs/financni_stabilita/makroobezretnostni_politika/ proticyklicka_kapitalova_rezerva/index.html >. [9 November 2014].

De Larosiere, J. et al., 2009. The High Level Group of Financial Supervision in the EU. Report, Brussels.

Directive 2013/36/EU on access to the activity of credit institutions and the prudential supervision of credit institutions and investment firms (CRD IV).

ECB, 2014. European Central Bank, Regulation (EU) No 468/2014 of the European Central Bank of 16 April 2014 establishing the framework for cooperation within the Single Supervisory Mechanism between the European Central Bank and national competent authorities and with national designated authorities (SSM Framework Regulation) (ECB/2014/17), Frankfurt am Main.

ECB, 2014a. European Central Bank, Guide to banking supervision, Frankfurt am Main. 
ESRB, 2013. European Systemic Risk Board, Recommendation of the European systemic risk board of April 2013 on intermediate objektives and instruments of macro-prudential policy.

Herring, R., 2011. The Capital Conundrum. Wharton Financial Institutions Center, Working Paper No. 11-70, Philadelphia, PA.

Monfort, B., Mulder, C.: Using Credit Ratings for Capital Requirements on Lending to Emerging Market Economies: Possible Impact of a New Basel Accord. IMF Working Paper 3, International Monetary Fund.

Revenda, Z., 2011. Centrální bankovnictví. Management Press, Praha.

SSM, 2013. Council Regulation (EU) No 1024/2013 conferring specific tasks on the European Central Bank concerning policies relating to the prudential supervision of credit institutions, Frankfurt am Main. 
